\title{
SWOT ANALYSIS TO DETERMINE A COMPANY'S STRATEGY IN THE STATE OF THE COVID-19 PLAGUE IN XYZ COMPANY
}

\author{
Safa'at \\ High School of Economic Mahardhika, Surabaya \\ safa'at@stiemahardhika.ac.id \\ Nuzulul Fatimah \\ High School of Economic Mahardhika, Surabaya \\ nuzulul.fatimah@stiemahardhika.ac.id \\ Muhammad Ali Ahmad \\ National College of Business Administration and Economics Lahore, Layyah Pakistan \\ aliahmadbzu@gmail.com
}

\begin{abstract}
PT. XYZ is a company engaged in the field of readymix concrete. This study aims to determine the company's strategy in a covid-19 epidemic state, it is hoped that the company will be able to deal with it well. The method used is by interviewing employees in accordance with their fields and collecting the necessary documents, from the data are evaluated and then the strategy is prepared. From the results of the study concluded that with the SWOT analysis the company's position is located in quadrant 4.
\end{abstract}

Keywords : SWOT, Covid-19 and Strategy

\section{INTRODUCTION}

The Corona or Covid-19 virus outbreak has had a significant impact on the global economy. In fact, after being officially declared a pandemic by the World Health Organization (WHO), the Covid-19 virus has increasingly pressed economic conditions in various sectors.

Various companies from various sectors have started to feel the losses caused by the spread of this virus. The outbreak of the Covid-19 Virus has also made some or even many entrepreneurs and companies in Indonesia and in the world feel a considerable impact.

A number of countries have started implementing social distancing policies to lockdown in their countries. In Indonesia, a social distancing policy and an emphasis on work from home (WFH) were adopted, but this policy directly or indirectly affects customer visits, besides that the company needs to keep running its business so as not to impact on employee dismissal which of course will cause more problems large.

Indeed, not all businesses can apply the WFH system, such as manufacturing, construction, retail, F\&B (restaurant), transportation, banking, and health businesses. This makes it a challenge for these businesses to continue to operate and run their business as well as possible so that the impact of this outbreak can be eliminated.

Minister of Public Works and Public Housing (PUPR) Basuki Hadimuljono received input from contractors so that infrastructure projects are temporarily suspended. This is in response to the COVID-19 pandemic so that construction service actors need to be careful. 
To prepare for this, Basuki allowed contractors to temporarily stop the projects they were working on, provided that the rights of project workers were still fulfilled, aka salaries were still given.

On the other hand, at the same time, the Minister of Finance issued a letter to all regional heads where the procurement of new goods and services was asked to be stopped and the budget was diverted for health, which means that only a few government projects are running and then continue from the ones already running, meanwhile procurement of new projects has been temporarily suspended.

To deal with this situation, the company must be able to establish the SWOT method as the basis for the formulation of its strategy, this strategy needs to be involved using the SWOT method as the main method, internal and external factors are the initial steps for carrying out strategies to optimize efforts to achieve success.

In the analysis of internal and external factors and taking into account all the aspects that are in the term S.W.O.T, namely (Strength) strength, (Weakness) weakness, (Opportunities) opportunity or opportunity, (Threats) threats.

\section{LITERATURE REVIEW}

\subsection{Strategy Concept}

Strategy is a tool to achieve the expected goals. During its development, the concept of strategy continues to develop. This can be shown by the existence of different concepts regarding strategy during the last 30 years (Rangkuti, 2013: 3). In line with that, Hamel and Prahaland (1995) also say that strategy is an incremental (constantly increasing) action and is carried out based on the point of view of what customers expect in the future (Rangkuti, 2013: 4).

According to Rangkuti's (2013: 6) opinion, strategies can be grouped based on three types of strategies, namely management strategies, investment strategies and business strategies :

\section{a. Management Strategy}

Management strategy includes strategies that can be carried out by management with a macro strategy development orientation. For example, product development strategy, pricing strategy, acquisition strategy, market development strategy, financial strategy, and so on.

b. Investment Strategy

This strategy is an investment-oriented activity. For example, does the company want to carry out an aggressive growth strategy or attempt to penetrate the market, a survival strategy, a strategy to rebuild a new division or a divestment strategy, and so on.

c. Business strategy

This business strategy is often called a functional business strategy because this strategy is oriented to the functions of management activities, such as marketing strategy, production or operational strategy, distribution strategy, organizational strategy, and strategies related to finance.

\subsection{SWOT}

\subsubsection{Definition}

According to Pearce and Robinson (2014), SWOT is an acronym for the internal Strength and Weakness of a company as well as Opportunities and opportunities and Threats the environment it faces. SWOT analysis (SWOT analysis) is a well-known historical technique whereby managers create a quick overview of the company's strategic situation. 
This analysis is based on the assumption that an effective strategy is derived from a good "fit" between the company's internal resources (strengths and weaknesses) and external situations (opportunities and threats). A good match will maximize the strengths and opportunities of the company and minimize weaknesses and threats. When applied accurately, these simple assumptions have profound implications for successful design and strategy.

\subsubsection{Analysis}

Rangkuti (2013: 19) argues that SWOT analysis is the identification of various factors systematically to formulate a company strategy. This analysis is based on logic that can maximize strength (Strength) and opportunities (Opportunities), but simultaneously can minimize weakness (Weakness) and threats (Threats). The strategic decision-making process is always related to the development of the company's mission, objectives, strategies and policies. Thus, strategic planning (strategic planner) must analyze the factors of the company's strategy (strengths, weaknesses, opportunities, and threats) in the current conditions. This is called a Situation Analysis. The most popular model for situation analysis is the SWOT analysis.

a. External Environmental Analysis (Opportunities and Threats)

According to Kottler and Kevin Lane Keller (2009: 51), a business unit must observe the main strength of the macro environment and significant micro environmental factors, which affect its ability to generate profits. Business units must establish external and internal marketing intelligence systems. Marketing opportunities are areas of buyers' needs and interests, where companies have a high probability of satisfying these needs profitably. Environmental threats are challenges posed by undesirable trends or developments that will result in decreased sales or profits due to the absence of defensive marketing measures.

b. Internal Environmental Analysis (Strengths and Weaknesses)

The ability to find attractive opportunities and the ability to take advantage of these opportunities are two different things. Every business must evaluate its internal strengths and weaknesses. SWOT analysis compares the external factors, opportunities and threats with internal factors. Strengths and Weaknesses.

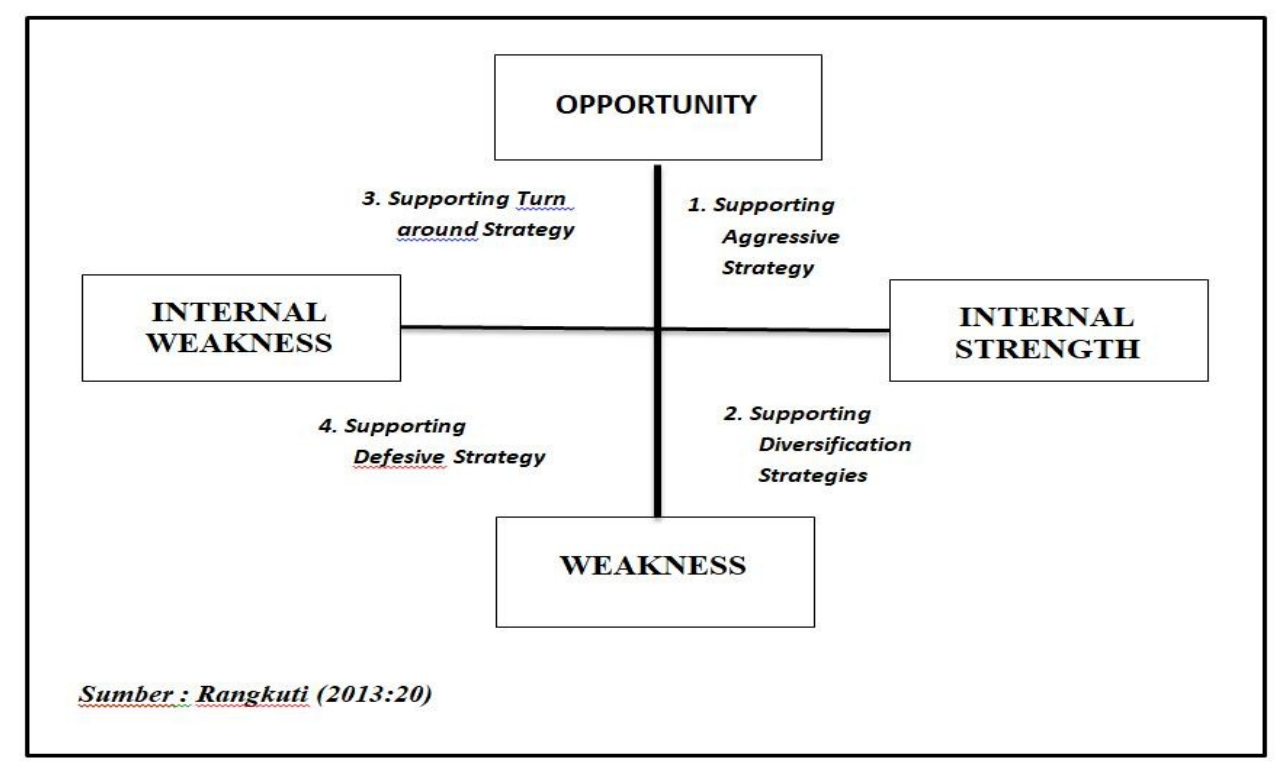

Figure 1. The Division of Quadrant SWOT Analysis 
Quadrant 1: This is a very favorable situation. The company has opportunities and strengths so that it can take advantage of existing opportunities. The strategy that must be applied in this condition is to support an aggressive growth policy (growth oriented strategy).

Quadrant 2: Despite facing various threats, this company still has strength from an internal perspective. The strategy that must be applied is to use strength to take advantage of longterm opportunities by means of a diversification strategy (product / market).

Quadrant 3: The company faces huge market opportunities, but on the other hand, it faces several internal constraints / weaknesses. The business conditions in quadrant 3 are similar to the Question Mark on the BCG Matrix. The focus of this corporate strategy is to minimize internal problems in the company so as to seize better market opportunities. For example, Apple uses a technology review strategy that is used by offering new products in the microcomputer industry.

Quadrant 4: This is a very unfavorable situation, the company is facing various internal threats and weaknesses.

\subsubsection{IFE Matrix and EFE Matrix}

\section{A. IFE (Internal Factor Evaluation) Matrix}

According to Umar $(1999 ; 172)$, there are five stages in developing the IFE Matrix, IFE Matrix can be developed in five stages, namely:

a. List the key success factors / aspects as identified in the internal factors, including their strengths and weaknesses.

b. Assign a weighted value between 0.0 (not important) to 1.0 (very important) for each factor. The weight value shows the relative importance of these factors to be successful in the company's industry. The factors that are considered to have the greatest role in the achievement of the highest value organizations and vice versa. The sum of all weights must be 1.0 .

c. Give a rating (value) of 1 to 4 for each factor to show whether the factor has a big weakness (rating $=1$ ), a small weakness (rating $=2$ ), a small strength (rating $=3$ ), and a low strength. large (rating =4). So actually, rating refers to the company whereas weight refers to the industry in which the company is located.

d. Multiply the weight and rating of each factor to determine the score.

e. Add up the total score for each variable. Its value is the value for the organization in terms of the IFE Matrix. The average score was 2.5. If the initial value is 2.5 it indicates that the company is internally weak, while a value above 2.5 indicates a strong internal position.

\subsubsection{EFE Matrix (External Factor Evaluation)}

According to Umar $(1999 ; 165)$, there are five stages in developing the EFE Matrix:

a. Make key success factors / aspects as identified in the external audit process that includes opportunities and threats.

b. Determine the weights of the key success factors on a scale from 0.0 (not important) to 1.0 (very important). The total weights of the key success factors must equal 1.0

c. Furthermore, regarding the value rating Each key success factor is given a rating between 1 to 4 , that present :

$4=$ very good response,

$3=$ response above average,

$2=$ average response,

$1=$ response below average. 
This rating is based on the effectiveness of the company's strategy, thus the value is based on the condition of the company.

d. Multiply each weight value by its rating value to get the score for all key success factors.

e. Sum all scores to get the total score of the company. Of course, in the EFE Matrix, the highest possible total score is 4.0 and the lowest is 1.0. A total score of 4.0 indicates that the company responds to opportunities in an extraordinary way and avoids threats in its industrial market. A total score of 1.0 indicates the company's strategies are not taking advantage of opportunities or avoiding external threats.

\subsection{Previous Research}

Research conducted by Reca Elyarni, Hermanto, entitled SWOT Analysis Study of SAP Express Service Marketing Strategy at PT. SAP, which concludes that based on the results of calculations obtained by PT SAP, is in quadrant 1 , it shows a very favorable situation for the company. After conducting a SWOT analysis, the following suggestions are given, namely: (1) more promotions to consumers so that they are widely known, (2) because of the large number of customer requests, PT SAP should open several branches and (3) PT SAP immediately implement new marketing strategies to make it more efficient .

\section{RESEARCH METHOD}

This research is a case study at a national scale readymix concrete company in East Java, with the object of documents relating to supplies, especially raw materials. In this study, the data used is secondary data where the data is obtained directly from the company and other data related to research.

\subsection{Data Collection Techniques}

The data collection technique required is done by several methods, including:

a. Interviews, namely obtaining data by conducting direct interviews with employees who are in accordance with their fields in the hope of obtaining data about the company description, the condition of the company in a state of an outbreak, both human resources, budget, marketing and other problems.

b. Documentation, namely obtaining data by collecting documents in which data is expected to be obtained about sales, market trends and finance.

\subsection{Data Analysis Techniques}

The stages of the analysis include:

1. Determine both internal and external environmental variables

2. Compile the IFE and EFE matrix tables

3. Analyze the company's position in the quadrant

4. All of the above are discussed with the company

\subsection{Research Object Profile}

\section{RESEARCH RESULTS AND DISCUSSION}

As the object of this research is a national scale readymix concrete company in East Java which was founded in 1989.

Along with the relatively high economic growth and the rapid development of the construction sector, particularly in infrastructure and property development, this company has participated by providing ready-to-use concrete products. 
Supported by staff of experienced employees in the field of concrete, proper equipment and group facilities, the company always prioritizes customer satisfaction and trust, by ensuring that the products produced meet the required quality, timely delivery of products and competitive prices.

\subsection{Description of Research Results and Discussion}

\subsubsection{Determining Environmental Variables}

To help obtain accurate data on environmental variables, both internal and external, a list of questions and questionnaires is needed. Questionnaires with closed question types already provide answers so that respondents only answer by circling $(O)$, ticking $(\sqrt{ })$, or crossing $(X)$ or moving the answers they are most correct (correct) in the contact answers provided.

\subsubsection{Evaluation Matrix}

The formulation of strategies used to summarize and evaluate the main variables in the functional areas of the business that have been obtained from distributed questionnaires, and also become the basis for identifying and evaluating the relationships between these areas, intuitive assessment is used in the development of an evaluation matrix for both internal environmental variables. as well as external.

Table 1. IFE Matrix

\begin{tabular}{|c|c|c|c|c|c|c|c|c|}
\hline \multirow{2}{*}{\multicolumn{2}{|c|}{ Aspect }} & \multirow[t]{2}{*}{ Quality } & \multicolumn{4}{|c|}{ Value } & Resume & \multirow[t]{2}{*}{ Score } \\
\hline & & & 1 & 2 & 3 & 4 & Value & \\
\hline \multicolumn{9}{|c|}{ Strenght } \\
\hline 1 & Brand & 0.15 & & 2 & & & 2 & 0.3 \\
\hline 2 & Flexible organization & 0.10 & & & 3 & & 3 & 0.3 \\
\hline 3 & $\begin{array}{l}\text { Reliable human } \\
\text { resources }\end{array}$ & 0.10 & & & 3 & & 3 & 0.3 \\
\hline 4 & Guaranteed system & 0.15 & & & 3 & & 3 & 0.45 \\
\hline & Total & 0.50 & & & & & & 1.35 \\
\hline
\end{tabular}

\begin{tabular}{|c|c|c|c|c|c|c|c|c|}
\hline \multirow{2}{*}{\multicolumn{2}{|c|}{ Aspect }} & \multirow[t]{2}{*}{ Quality } & \multicolumn{4}{|c|}{ Value } & Resume & \multirow[t]{2}{*}{ Score } \\
\hline & & & 1 & 2 & 3 & 4 & Value & \\
\hline \multicolumn{9}{|c|}{ Weakness } \\
\hline 1 & $\begin{array}{l}\text { Marketing model } \\
\text { (network) }\end{array}$ & 0.15 & & & & 4 & 4 & 0.6 \\
\hline 2 & Product quality & 0.15 & & 2 & & & 2 & 0.3 \\
\hline 3 & $\begin{array}{l}\text { Work plan and } \\
\text { budget }\end{array}$ & 0.10 & & & & 4 & 4 & 0.4 \\
\hline 4 & Corporate culture & 0.10 & & & 3 & & 3 & 0.3 \\
\hline & Total & 0.50 & & & & & & 1.6 \\
\hline
\end{tabular}

From the analysis results in table 1. IFE strength factor has a total score of 1.35 while weakness has a total score of 1.60 
Table 2. EFE Matrix

\begin{tabular}{|c|c|c|c|c|c|c|c|c|}
\hline \multirow{2}{*}{\multicolumn{2}{|c|}{ Aspect }} & \multirow[t]{2}{*}{ Quality } & \multicolumn{4}{|c|}{ Value } & Resume & \multirow[t]{2}{*}{ Score } \\
\hline & & & 1 & 2 & 3 & 4 & Value & \\
\hline \multicolumn{9}{|c|}{ Opportunity } \\
\hline 1 & National development & 0.15 & 1 & & & & 1 & 0.15 \\
\hline 2 & Main product & 0.10 & & & 3 & & 3 & 0.3 \\
\hline 3 & Trust and customers & 0.15 & & 2 & & & 2 & 0.3 \\
\hline 4 & Trust and external resources & 0.10 & 1 & & & & 1 & 0.1 \\
\hline & Total & 0.50 & & & & & & 0.85 \\
\hline \multirow{2}{*}{\multicolumn{2}{|c|}{ Aspect }} & Quality & \multicolumn{4}{|c|}{ Value } & Resume & Score \\
\hline & & & 1 & 2 & 3 & 4 & Value & \\
\hline \multicolumn{9}{|c|}{ Threat } \\
\hline 1 & $\begin{array}{l}\text { The emergence of } \\
\text { competitors (price } \\
\text { competition) }\end{array}$ & 0.10 & & & 3 & & 3 & 0.3 \\
\hline 2 & Mastery of market share & 0.15 & & & 3 & & 3 & 0.45 \\
\hline 3 & Limited sources of funds & 0.15 & & & & 4 & 4 & 0.6 \\
\hline \multirow[t]{2}{*}{4} & Crisis conditions & 0.10 & & & 3 & & 3 & 0.3 \\
\hline & Total & 0.50 & & & & & & 1.65 \\
\hline
\end{tabular}

From the results of the analysis in table 2. EFE the opportunity factor has a total score of 0.85 while the threat has a total score of 1.65 .

\subsubsection{Quadrant Analysis}

From table 1 and table 2, the coordinates are calculated and the cartesian diagram is drawn to determine the quadrant position of the company.

Table 3. Coordinate Calculations

\begin{tabular}{|l|l|l|l|}
\hline \multicolumn{4}{|c|}{ Coordinate Calculation } \\
\hline Indicator & Score & Indicator & Score \\
\hline Strenght & 1.35 & opportunity & 0.85 \\
\hline Weakness & 1.60 & threat & 1.65 \\
\hline Deviation & -0.25 & deviation & -0.80 \\
\hline
\end{tabular}

From table 3.Calculation of coordinates, by subtracting the strength score from the weakness score, the value of -0.25 is obtained as the $\mathrm{X}$-axis coordinate. 


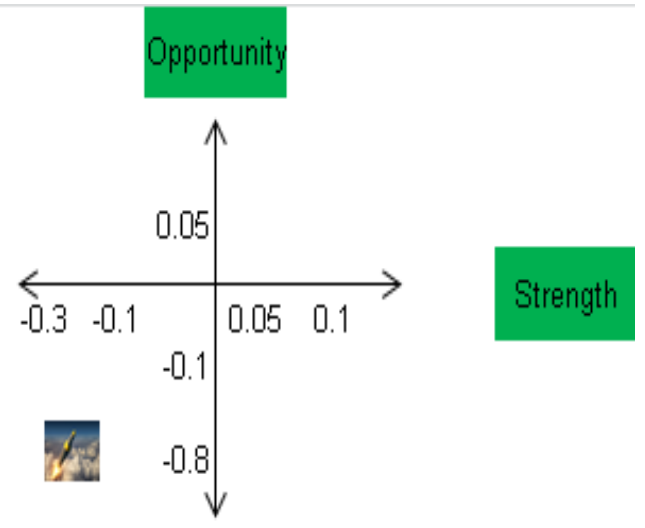

Figure 2. Coordinates from Table 3

From the coordinate image in the Cartesian diagram above, it is known that the company is located in quadrant 4.

\subsection{Conclusion}

\section{CONCLUSIONS AND SUGGESTIONS}

From the data processing and analysis that has been carried out, it can be concluded that the company's position is located in quadrant 4 which means this is a very unfavorable situation, the company is facing various threats and internal weaknesses.

Entering this quadrant proves that the company's condition is no longer as expected. In a difficult situation like this, what is needed is to survive while maintaining internal performance so that the wheels of the organization keep running. Companies must be courageous and fast in taking new breakthroughs so that what was a threat can become an opportunity for the company.

\subsection{Suggestions}

\section{For companies:}

1. Utilizing resources to seize business opportunities in a crisis, for example switching to medical equipment, education, groceries and other businesses which are the basic needs of society. However, the business transition must examine the legal side (the company's articles of association and shareholder approval) as well as the capital requirements for investment.

2. If advice no. 1 is not possible to implement, then the company must take advantage of its strengths to seize the slightest opportunity and face threats. Among them that can be done are:

- Increase sales productivity by utilizing social media to market their products

- increased inflow with receivable withdrawals and cash sales

- carry out efficiency and cost restrictions to increase the competitiveness of selling prices

- Increase stock turnover by producing products according to orders only

For further research:

1. For further research, it is hoped that more samples will be taken to make the strategy more general. 
Journal of Islamic Economics Perspectives, Volume 3. Issue 2 (2021)

\section{References :}

Rangkuti, Freddy, 2013, SWOT Analysis Technique of Dissecting Business Cases, Jakarta: Gramedia Pustaka Utama

Robinson, Pearce, 2014, Strategic Management Formulation, Implementation, and Control, Jakarta: Bina Rupa Aksara

Kotler, Philip and Keller, Kevin Lane, 2009, Marketing Management, Jakarta:Indeks

Reca Elyarni, Hermanto, 2016, SWOT Analysis of SAP Express Service Marketing Strategy in SAP Company, Journal of Industrial Engineering, Metric Journal, 17(2016): 8188

H, Umar, 1999, Corporate Strategy Research, PT. Gramedia Pustaka Utama

Sondang P.Siagian, 1995, Management Strategic, Jakarta:Bumi Aksara

Michael A. Hitt, dkk, 1997, Strategic Management Towards the Era of Globalization Competition, Jakarta: Erlangga

Rusdiansyah, 2016, Billing Application Strategy Analysis with the SWOT Method, BINA INSANI ICT JOURNAL, Vol. 3, No.1, Juni 2016, 145 - 153, ISSN: 2355-3421 (Print) ISSN: 2527-9777 (Online)

Hanim Khalida Zia1, Rima Semiarty2, Ratni Prima Lita3, 2018, SWOT ANALYSIS AS A DETERMINER OF MARKETING STRATEGY IN BAITURRAHMAH DENTAL HOSPITALS, PADANG, jurnal.fk.unand.ac.id

Rahmayati HM, 2015, SWOT Analysis in Determining The Marketing Strategy OF Frozen Shrimp, PT. Mustika Mina Nusa Aurora Tarakan, North Borneo, Journal Galung Tropika, 4(1) January 2015, page 60-67 